\title{
FROM NORDIC NOIR TO BELGIAN BRIGHT?
}

\section{SHIFTING TV DRAMA PRODUCTION AND DISTRIBUTION IN SMALL MARKETS: THE CASE OF FLANDERS}

Tim Raats imec-SMIT, Vrije Universiteit Brussel tim.raats@vub.be

Catalina lordache

imec-SMIT, Vrije Universiteit Brussel catalina.iordache@vub.be

\begin{abstract}
Shifts in audio-visual production, distribution, and consumption have increased pressure on broadcasters as main financiers of domestic content in Europe. However, within the context of internationalisation and digitalisation, there are also new opportunities for the export of European content. By taking a close look at the evolution and increasing popularity of Flemish TV drama, this article identifies key explanatory factors for the export of content produced in a small media market. The analysis also discusses the extent to which the rise in exports may contribute to the increased sustainability of a small and fragile, yet vibrant audio-visual industry.
\end{abstract}

Keywords: Flanders, Belgium, distribution, co-production, transnational television, small media market, TV drama

\section{Introduction}

Non-linear viewing, cut-backs at the level of public service broadcasting, a shift in advertising spending from legacy media to online players, and the introduction of over-the-top players like Netflix or Amazon have put significant pressure on existing TV drama financing and on broadcasters, the main financiers of domestic content in Europe. ${ }^{1}$ This is particularly the case in smaller television markets, which are traditionally more dependent on public support, ${ }^{2}$ have a limited domestic market, and less potential for export. ${ }^{3}$ However, new platforms and services also increase opportunities for export and recoupment of TV drama investments. The popularity of European series on Netflix or services like UK's Walter Presents clearly show the cross-border potential of small markets. In that regard, it was the global success of Danish drama produced by public broadcaster DR that paved the way for other small markets. What the success of Danish drama revealed was the importance of distinct strategies that prioritise screenwriting within the production process, ${ }^{4}$ as well as co-production and co-financing partnerships with European distributors and other broadcasters. ${ }^{5}$

Strategies like these have been picked up widely, not in the least in Flanders, the Dutch-speaking part of Belgium. Similar to the Danish case of Forbrydelsen (The Killing, 2007-2012), ${ }^{6}$ it was the programming of a crime drama 
(Salamander, 2012-2018) on BBC Four's Saturday night slot in 2014 that initiated international attention for Belgian drama. Since then, Flanders has seen a spectacular uptake in the export of its television drama, with titles like Hotel Beau Séjour (2017-), Tabula Rasa (2017-), or Professor T. (2015-2018) being sold and remade internationally.

This article adopts a political economy approach, ${ }^{7}$ which enables a holistic, macro- and meso-level approach, in order to contextualise the shift in Flemish TV drama strategy from a purely domestic to an international focus. This did not only result from the increase of distribution outlets, but also from the interplay between broadcasters, producers, cable distributors, and the Flanders Audiovisual Fund. The research was motivated by a gap in existing literature, particularly focused on strategies and exports of the genre, originating in small media markets. To this end, the article first addresses the context of small markets and identifies the key strengths of the Danish drama model, which clearly influenced the strategic shift in Flanders. The research questions addressed are, firstly, 'what are the key factors in explaining the increased export of Flemish TV fiction?', and, secondly, 'to what extent does increased export also contribute to increased sustainability of a small and fragile, yet vibrant, audio-visual industry?' The case study then provides an analysis from 'Nordic Noir made in Flanders' with Salamander (2012-2018) in 2014, to Belgian drama being picked up internationally as 'Belgian Bright' or 'the New Scandi-Noir'. ${ }^{8}$ It subsequently focuses on four components explaining the uptake in exports: (i) increased availability for non-English TV drama; (ii) a focus on high-concept genre; (iii) a focus in policy supporting the export of drama; (iv) co-productions as the new standard for high-end drama. The case study analyses a variety of data, including production information (volume, budgets, sales/territories), press statements, policy documents (management agreements, vision notes, etc.), complemented by a series of expert interviews, conducted between April 2016 and May 2019. Interviewees include independent producers, the management of the Flanders Audiovisual Fund, commissioning editors at VRT and private broadcaster DPG, and VRT business strategists. The article primarily focuses on Flemish drama, although broader discussions on canned export of Walloon (French-speaking Belgian) drama are also included in the paper for increased context, but not analysed in-depth, as the two Belgian markets are quite different. As such, this study both fits within a growing case study-based research on small television markets, ${ }^{9}$ as well as recent literature strands within media economics focusing primarily on the sustainability of television markets. ${ }^{10}$

\section{Exporting Television Content in Small Media Markets}

\subsection{How "Smallness" Affects Export Capabilities}

In order to set the scene for the Flemish case, it is worth examining the characteristics of small markets, with a focus on those that impact the export of content. There is no consensus on which indicators precisely define a television market as 'small', and various aspects such as the number of domestic players and turnover might affect its 'size'; but usually, population is used to demarcate the difference between small and large markets. ${ }^{11}$ In line with Puppis' definition of 'small states', ${ }^{12}$ we consider markets with a population of less than 14 million inhabitants as small. In practice, bar exceptions such as the UK, Poland, France, Spain, and Germany, most European states could be considered small markets. According to Eurostat data from 2019, the region of Flanders has approximately 6,5 million inhabitants.

The first important factor relates to budget. Small television markets are characterised by a limited number of players, with the public service broadcaster often playing a key role as the driver of the television ecosystem. ${ }^{13}$ Small markets also have a lower number of independent commissioners which are often stuck between the challenge of limited outlets (given the small number of broadcasters) to provide content for, and limited capacity to increase profit margins by recouping funds. The latter has to do with the size of the domestic market. This in turn negatively affects the revenue of private broadcasters, due to limited advertising income; the resources allocated to public broadcasting funding and audio-visual funds; and the interest of domestic pay-TV services to invest significantly in domestic production. As such, exporting content becomes part of increasing the sustainability of small markets. 
Moreover, investing in original TV drama is highly expensive compared to acquiring foreign rights for content. ${ }^{14}$ Small markets generally produce smaller volumes of TV fiction. This impedes the potential of export as a constant flow of high-quality TV drama on the international market, which is often considered crucial for buyers. For Flanders, research indicates that purchasing a foreign drama is eleven times cheaper than investing in a domestic TV drama. ${ }^{15}$ At the same time, the production budgets of foreign series are up to nine times the size of the budgets of Flemish series. In consequence, small markets show a particular dependence on public funding,$^{16}$ either directly from subsidies or from investments made by the public service broadcaster. Moreover, recent years have brought additional insecurity in the shape of non-linear viewing, which has also increasingly put pressure on the viewer ratings and advertising income of broadcasters. ${ }^{17}$ Media use has shifted towards transnational subscription-based video-on-demand services (SVOD), whose quality offerings for a monthly subscription compete directly with the offerings of traditional broadcasters. Scale advantages allow these new players to compete with relatively cheap subscription fees but significantly larger catalogues, consisting primarily of foreign content. ${ }^{18}$ Moreover, platforms like Google and Facebook are also competing with domestic players for advertisement revenue. A recent study ${ }^{19}$ found that more than half of all online advertisement in Europe flows to U.S. corporations Google and Facebook, revenue that does not get re-invested in the production or distribution of original European content. Nevertheless, European players produce and release an increasing number of European TV fiction ${ }^{20}$ and films, dwarfing U.S. output for film. ${ }^{21}$

The result is that domestic audio-visual production is characterised by limited budgets. In theory, the lack of budget scale limits the opportunities of export on the international market, where small-budget productions are competing with big-budget international offerings. Larger budget usually allows for higher production quality: more shooting days, resources for script development, shots on location, visual effects, etc. Therefore, in order for content to be exported, more money must be invested; at the same time, more money can come from export. This takes the form of a 'catch-22'. Strategies to counter these competitive disadvantages include first exploring opportunities to enlarge the scale of a production by co-producing with other broadcasters or involve co-financing, in which a third-party distributor provides a 'minimum guarantee' on the distribution revenue. Overall, there need to be additional forms of financing involved to work as a lever in generating this return. In the case of small markets this often comes in the form of cofinancing collaborations such as Nordvision in the Nordic countries, tax levies, and public broadcasting investments.

A second strategy is to prioritise screenwriting and high-concept TV fiction, with the aim of developing distinctive, and thus more attractive, original content, which may be picked up for international remakes. The Swedish-Danish crime drama Bron/Broen (The Bridge, 2011-2018) was exactly that: a business model driven by an ambition to expand the domestic market beyond Sweden and provide a bigger budget production. ${ }^{22}$ This resulted in a co-production with two broadcasters (SVT and DR), and a high-concept premise that made Bron/Broen a lucrative concept for remakes, resulting in six localised versions and a seventh one currently in the making. Therefore, small budgets do not necessarily imply less potential for export.

The third factor relates to cultural specificity and language, which can also form an important barrier for content export. ${ }^{23}$ The popularity of Scandi-noir is based in part on the fact that series in the Nordic countries can secure higher budgets due to the Scandinavian geo-cultural market, which results from a traditionally higher cultural proximity ${ }^{24}$ between these countries. This increases the chance that a Swedish series, for example, is picked up by Norwegian and Danish viewers. ${ }^{25}$ But using a 'similar language' is not necessarily the basis for success. In Flanders and the Netherlands, for example, despite sharing the Dutch language, films and television series are often remade ${ }^{26}$ rather than imported and watched in their original form. Moreover, small markets that share a language with a neighbouring larger market (Austria, Ireland, Wallonia) have struggled to develop a sustainable domestic content industry, given the popularity and high market share of content imported from these foreign players. Original drama productions are often so-called 'minority co-productions' in which the small market only has a limited stake. On the other hand, once a series receives critical acclaim, there is a substantial potential to bypass these structural barriers. In that regard, one of the most promising developments over the past decade comes from Wallonia, where a joint public broadcaster and government fund (Fonds RTBF-FWB) started to produce $100 \%$ domestic TV drama. The government support ensured the funds for the series to be produced, and language proximity helped in the series being picked up immediately in France and by streaming services such as Netflix, as in the cases of Ennemi Public (Public Enemy, 2016-), La Trêve (The Break, 2016-), and 
Unité 42 (Unit 42, 2017-). As no French co-producer was involved, the revenue flowed back to Wallonia, in turn determining a significant rise in local production volume, based on a strategy that has international export at its core. The fragmentation of the European market, characterised by significant differences between large and small Member States, and myriad cultural communities and languages, has traditionally forced European players to mostly focus on domestic markets. The tradition of focusing on domestic content also partly resulted from the fact that TV drama production was often left to public broadcasters, as broadcast monopolies were only broken up at the end of the $1980 \mathrm{~s}^{27}$

\subsection{Flanders - An Atypical Typical Small Market}

As cultural industries and media consumption are completely separate in the French and Flemish communities, what constitutes the 'Belgian audio-visual sector' is in fact two separate markets, portraying the characteristics of small television markets. Flanders demonstrates the limits of a small television market: limited audiences and thus limited potential for return on investment, limitations on export due to language and lack of scale, and a limited number of players. ${ }^{28}$ The public service broadcaster VRT and two private broadcasters (DPG and SBS) are the main commissioners and producers of TV drama in Flanders. Since 2014, digital television providers Telenet and Proximus have been increasingly investing in television fiction as well, partly by funding preview, transaction(TVOD) and subscription-video-on-demand (SVOD) rights to enlarge their pay-TV subscription catalogues, and partly because they are forced by the government to invest in audio-visual production following the launch of the so-called Stimulation Decree (2014). The independent production industry is scattered across more than 60 companies, of which an average of 8 are consistently involved in TV fiction production.

Despite its limited scale, the television market in Flanders is a vibrant one, characterised by a significant proportion of domestically produced television content, due to its enormous popularity. In 2019 alone, a total of 16 television fiction series (including high-end drama, children's fiction and sitcoms) were broadcast on television. ${ }^{29}$ The main struggles to sustain television production follow from the increased percentages of delayed viewing, especially in the genre of TV fiction, which puts considerable pressure on both private broadcasters to sustain the genre. In 2018, $17.5 \%$ of the total viewing was time-shifted in Flanders, going up to $32.7 \%$ for the age group $18-54$ for commercial broadcasters, the primary target group for advertisers. ${ }^{30}$ Added to that is the competition from non-domestic SVOD services such as Netflix. Audience research showed that $21 \%$ of the Flemish population has Netflix, and within the age groups of $16-24$ and $25-34$-year olds, respectively, $55 \%$ and $59 \%$ had access to Netflix in $2018 .{ }^{31}$

\section{Export of Flemish Drama: An Unnecessary Evil? (1990s-2010s)}

Unsurprisingly, Flemish TV fiction export patterns follow the trends of most small media markets, with limited exports especially due to language specificity. An exception here is the Dutch market, which has always been the most, and often only, buyer of Flemish fiction, followed by Wallonia. Up until private broadcasting was established in 1989, the Belgian public broadcaster BRTN developed a long-standing co-production tradition with the Netherlands for TV drama, amongst others supported through the Dutch-Flemish 'Cobo-fund'. ${ }^{32}$ Collaborating was considered a financial necessity in the first place, yet productions were often criticised for their arbitrary production choices following a complex financial model. Aside from these co-productions, sales of canned fiction programming were quite limited.

From the 1990s onwards, private broadcaster VTM has actively invested in TV fiction production, primarily for the domestic market. The public broadcaster, struggling with the enormous popularity of commercial television, increased its own TV drama volume and focused on more popular domestic TV drama as well, especially with hit crime series such as Witse (2004-2012) and Flikken (Cops, 1999-2009), and contemporary family sagas. ${ }^{33}$ The purely domestic focus on TV drama also resulted in little interest and effort to invest in export potential or promotion. Series that 
managed to secure worldwide distribution were always the result of the producer's efforts. Titles include Vermist (Missing, 2008-), which was the first Flemish series to be sold to France (2008-), followed by 92 other markets, ${ }^{34}$ and Matroesjka's (2005-2008), of which both seasons were sold to over 60 countries, including large territories such as Germany, UK, France, Brazil, and Australia.

The broadcasters' purely domestic focus also increased pressure on the genre, which led to different forms of government support that exist today to sustain TV drama and encourage broadcasters to keep investing. Aside from a subsidy mechanism (Mediafonds) of the Flanders Audiovisual Fund (VAF) and the abovementioned investment obligation for distributors, the fiscal incentive of the tax shelter has been of crucial importance in sustaining high levels of production. Estimates reveal a tax shelter adds over 85 million Euro to audio-visual production. ${ }^{35}$ The availability of these additional funding mechanisms reduced the necessity to attract co-production or co-financing support from foreign markets.

Interestingly, in most of the interviews we conducted, various producers pointed to examples of so-called 'Europudding' productions as reasons to avoid co-production and co-financing deals. The result was a strengthening of the domestic focus of TV drama production in Flanders, a growth of the production industry that depends almost entirely on the commissions of three big players, and a continuous pressure on these broadcasters to keep financing sufficient volumes. Another result was that, following two decades of audio-visual professionalisation, increasing turnover and companies, domestic audio-visual production was still considered 'precarious' and 'under increasing pressure'. And yet, something has clearly changed since 2014.

\subsection{Salamander and 'Nordic Noir from Belgium': An Uptake in Exports}

In 2012, VRT broadcast the 10-series crime drama Salamander (VRT and Skyline, 2012-2018) on its Sunday evening prime time slot. The series enjoyed high domestic popularity but, aside from its higher production budget, it was not significantly different from earlier Flemish TV drama projects. The series was sold in 2013 to BBC which broadcast it on its BBC Four Saturday night foreign drama slot in 2014. Following this, Salamander was also sold to numerous other markets, including the U.S. The sale of Salamander kick-started the expansion of worldwide sales of Flemish TV fiction and opened the door for the sale of Cordon (Containment, VTM and Eyeworks, 2016), which was also picked up by BBC and later got an, unfortunately unsuccessful, remake on the U.S. channel The CW Series. Since then, we have witnessed a spectacular rise in exports, with 2018 marking an important momentum in terms of popularity, as Belgian drama on international television markets as well as in public was coined the next 'Scandi-noir'. ${ }^{36}$ Since 2016, visibility of Flemish TV drama at international markets and festivals has markedly increased, with titles being selected, nominated and/or winning in Cannes Series (France), Serie Series (France), C21 (UK), or Series Mania (France), and the International Emmy Awards (U.S.), where labels such as 'Belgian Bright' or 'Flemish Noir' were coined to promote new drama productions.

The table below provides an overview of the uptake in exports of Flemish series, showing examples of various TV fiction series from all broadcasters since 2012. The table is based on data collected through press releases, VRT/VAF annual reports, and stakeholder interviews. Based on the mapping below, a number of lessons can be drawn. First, all productions belong to a Flemish production company in co-production with a Flemish broadcaster. In most cases, it is the production companies that took the lead in exploring international interest. Second, most of the series were sold immediately after the first (or only) season, the lack of large volumes having prevented further foreign sales. ${ }^{37}$ Third, part of the export deals (e.g. Netflix) were negotiated by the producers, and part were sold through external distributors. Another important outlet was the Channel 4 streaming service Walter Presents, which picked up Flemish fiction not only for UK viewers, but also included them in their international territory offerings, such as 13 Geboden (13 Commandments, 2017-), Spitsbroers (The Score, 2015-), or Professor T (2015-2018). For Flanders, just like for Denmark, ${ }^{38}$ ZDF Enterprises formed an important partner for several TV drama productions. Finally, in terms of genre, unsurprisingly, most series are crime fiction, which is also in line with scholarly findings on the popularity of the crime sub-genre for export. ${ }^{39}$ 


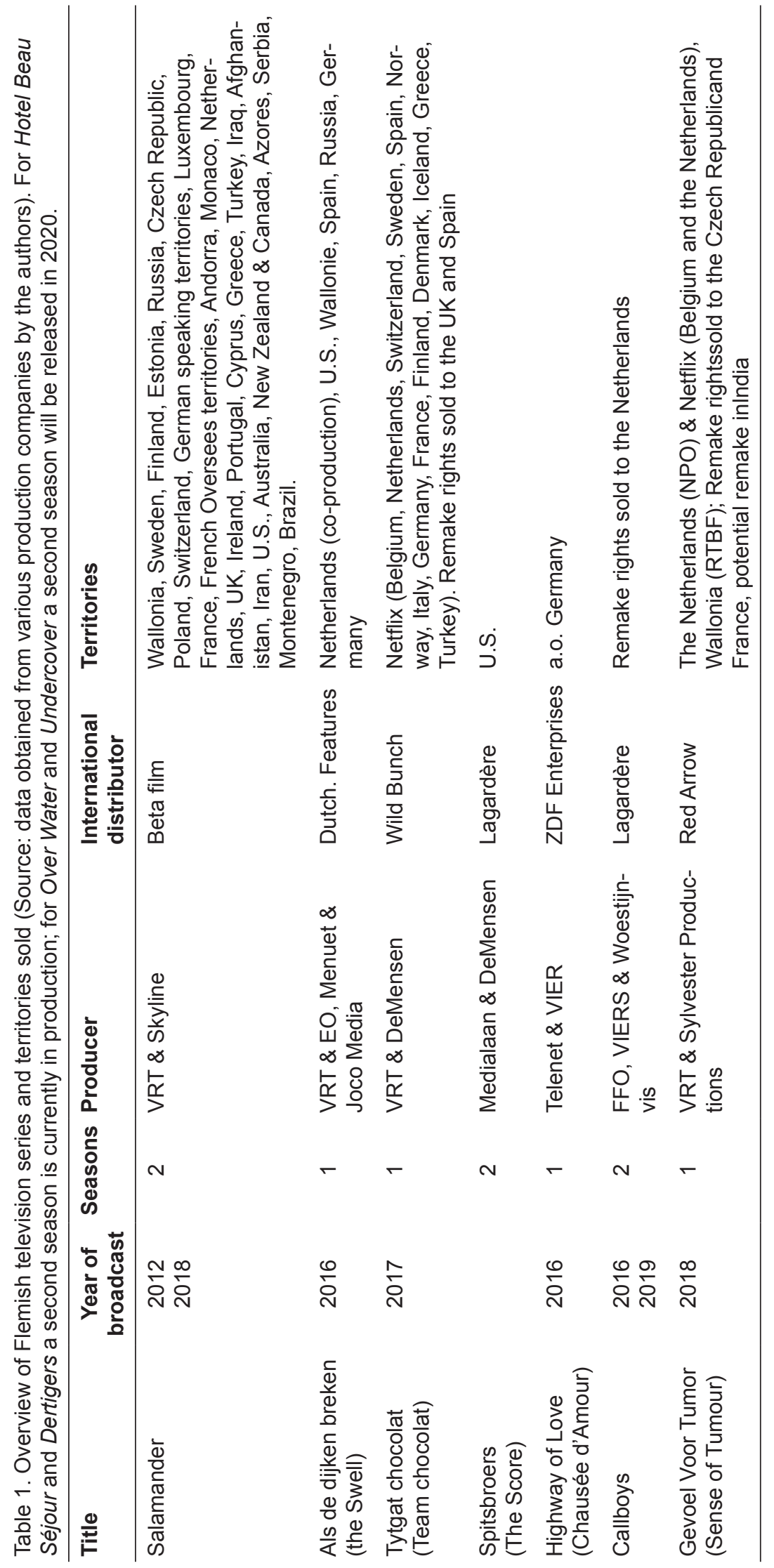




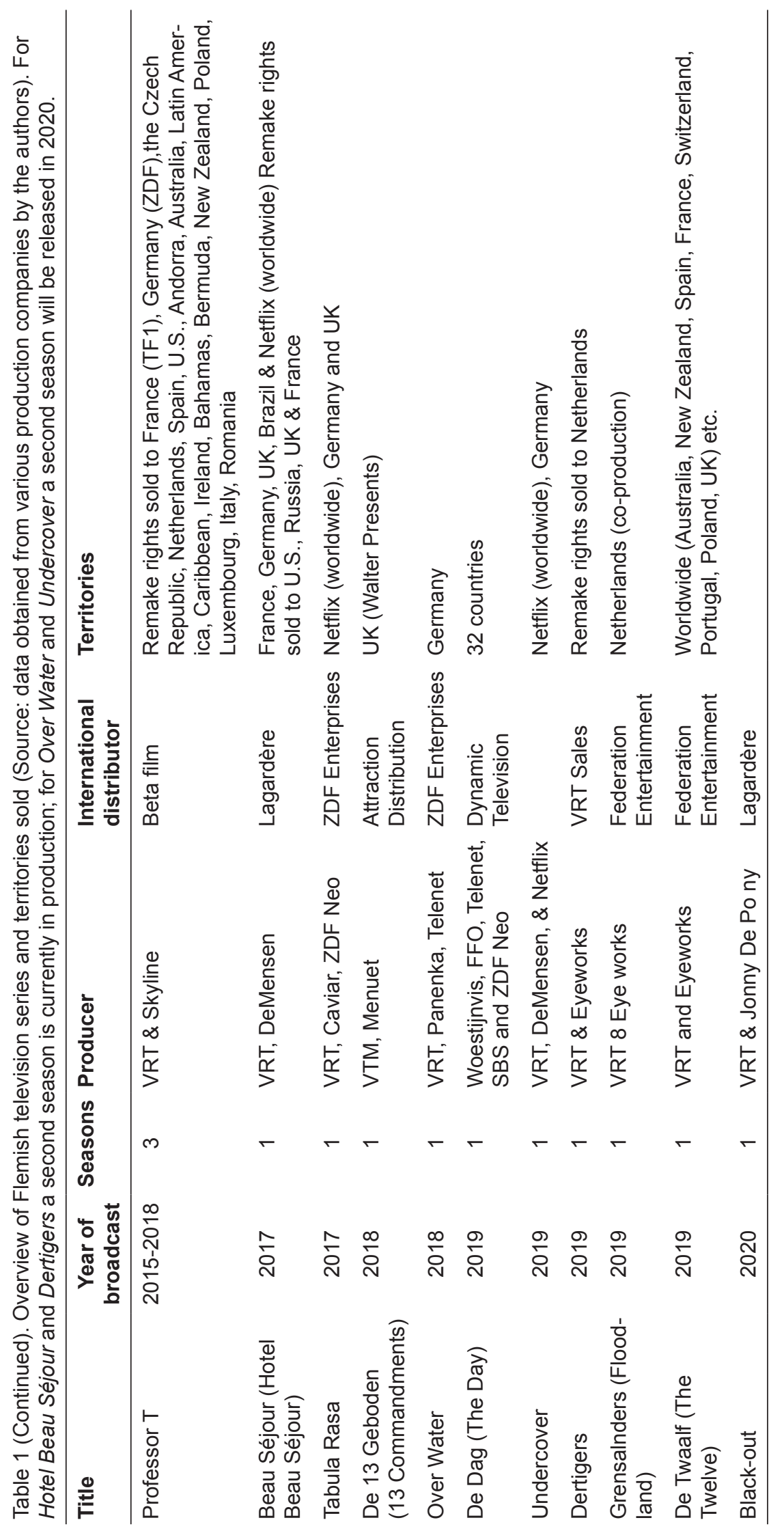




\title{
4 Explainingthe Success of Flemish TV Drama Exports
}

\author{
4.1 Increasing Capacity of Outlets for Non-English \\ Language Drama
}

\begin{abstract}
A first explanation for the increasing success of Flemish drama is the general increase in outlets for non-English language drama. In Europe, programming of non-national European television fiction has always been limited, bar exceptions for English-language (in practice BBC content) or content from countries sharing a language (WalloniaFrance, Austria-Germany, etc.). Exceptions that paved the way for foreign language drama were the Nordic crime dramas, which were, amongst others, kick-started with the sale of Forbrydelsen (The Killing, 2007-2012) to BBC Four as the first non-English language programme to be broadcast in its crime drama slot. ${ }^{40}$ Scandinavian drama and its foreign success helped create the appetite for foreign drama, which is amongst others visible in various crime dramas emulating the pace and storytelling of crime noir (see Hinterland/Y Gywyll, 2013-2016), ${ }^{41}$ with series like Salamander (2012-2018) even explicitly branded by its distributor Red Arrow as 'Nordic Noir from Europe'. However, it wasn't until international TV streaming services took off in Europe that export of non-English language European TV fiction increased. This had several consequences.
\end{abstract}

First, this increased outlets for sales on international streaming platforms but also for pay-TV offerings of European TVOD and SVOD services (e.g. Sky, Canal+, Telenet). Second, this allowed for new specialised services for European drama to appear (e.g. Walter Presents). Third, it intensified the race for rights and content on the European market with streaming channels, with players like ZDFe looking increasingly beyond Nordic countries at what could be the next big hit and getting involved in productions at a much earlier stage in order to already secure rights (similar to the strategy of some transnational streaming players). Fourth, in competing with these foreign platforms to retain domestic audiences, it also incentivized broadcasters to reposition themselves amidst streaming giants, amongst others, by investing in bigger budget productions in order to meet quality and audience expectations and exploring coproductions with other broadcasters, which in turn led to increased export capacity.

For content producers, the advent of these distribution services theoretically provided an additional outlet for expanding budgets, and valorising return on investment. Yet, in practice, various media professionals and policymakers feared an increasing fragmentation of financing, and a return that did not compensate for losses incurred from direct competition with platforms. The rise of these distribution outlets also partly nuances the importance of Flanders as 'the next big thing', given the fact that various countries have seen an uptake in exports following the explosion of available catalogues across Europe (see, for example, the success of French-speaking Belgian, Israeli, or Italian drama).

\subsection{A Focus on Exportable Genre and Theme}

A second explanatory factor for the success of Flemish drama is the rise of crime drama and high-concept drama. There is a common understanding among the industry professionals we have interviewed of what more 'attractive' high-concept series are. They often refer to universal themes, in combination with local flavour, a high-concept pitch, and building on the success of proven concepts (such as Nordic noir). Crime travels well, humour hardly so. ${ }^{42}$

Industry professionals have emphasised that high-concept premises and screenwriting are in demand, as viewers are used to edgier, more daring content. Therefore, Flemish broadcasters were encouraged to take a leap and move away from the 'comfortable' genres. The fact that this type of content lends itself to export was considered of secondary importance, although producers emphasised that it was increasingly taken into account. For public and 
private broadcasters, these daring concepts also constituted a risk. Storytelling that was too complex, controversial themes or genre crossovers of horror and crime were considered risky for domestic audiences, especially for private channel VTM. ${ }^{43}$ At the same time, producers and screenwriters emphasised the importance of local authenticity to raise a production's profile, often referring to Scandi-noir examples in motivating their answers. Cases like Hotel Beau Séjour (2017-), that sets out from a high-concept premise of a girl investigating her own murder as a ghost, are integrated in a typically local Flemish setting, with actors speaking local dialect and a theme song in the Limburg dialect. ${ }^{44}$ Series that attempted to look too 'U.S.-like', as one producer called them, were considered more likely to fail due to their lack of authenticity.

\subsection{A Policy Focus Privileging Exportable Content}

A third factor that explains the success of Flemish exports lies in the combination of government and film agency policies supporting exportable TV series, a trend that can also be seen at EU level through the setting of a new agenda and raising awareness amongst domestic policymakers and industries about the consequences of transnational media platforms entering European markets. ${ }^{45}$ One of the aspirations of the previous Flemish government, responsible for media policy, was an increased focus on internationalisation and return on investment. Policy vision statements included commitments to: (i) sustain or increase the quality of TV drama; (ii) strengthen the business model; (iii) invest in new formats; (iv) increase attention given to screenwriting; (v) increase the export of Flemish TV content. ${ }^{46}$ Heavily inspired by the success of the Danish TV drama model, and following various claims by broadcasters and independent producers, the government's goal to increase commercial return translated into a slight increase in the budget of the Flemish Media Fund (VAF). The management contract 2018-2021 (negotiated with VAF) included some changes that would form the translation of this strategy. In order to boost the quality of screenplays, screenwriting grants went up from 25,000 to 75,000 Euro, while production support for exportable high-end drama went up from 800,000 to 1,125,000 Euro, and the second series of successful titles would be awarded Media Fund grants. However, the criteria for what qualified as 'exportable' was not defined, therefore existing quality measures, such as screenplay quality, budget, crews, international co-financing are still considered when selecting eligible projects.

The result was a 'less is more' strategy: fewer high-end TV drama projects would be funded with the existing budget of the Media Fund. At the same time, the fund increased efforts to put screenwriting more at the centre of its training and networking initiatives, launching a bi-yearly 'Storycon', adding screenwriting coaches for more inexperienced writers, as well as launching a 'Concept Atelier Scenario', which allowed young talent to develop good concepts in collaboration with acclaimed showrunners. Since 2017, the film agency also hosts Connext, an annual event which brings international buyers to Belgium to showcase the latest Flemish productions.

Finally, the public broadcaster VRT also put exportable content at the forefront of its TV drama strategy, and increasingly explores business opportunities on the international market, on its own. The latter has resulted in tensions with producers, who feel the broadcaster is poaching too much on their territory and feel they are best suited to exploit the rights of their own productions internationally. ${ }^{47}$

\subsection{The TV Drama Co-production as the New Normal}

A fourth explanation for the success of 'Belgian Bright' lies in the gradual rise of co-productions, which is, in fact, a consequence of the increasing international popularity of Flemish TV drama. For example, the success of Salamander (2012-2018) allowed the involvement of Beta Film as a co-financing partner in the second series. ZDFe, which has 
been increasingly interested in Flemish drama since 2016, took minimum guarantees in some series (Over Water, 2018-; Tabula Rasa, 2017-) or directly invested as a co-producer in others (De Dag, 2018). Other co-production partners include ARTE, or the Dutch public service broadcasting organisations.

In 2019, the first 'Netflix original' Undercover (2019-) was co-produced with VRT and DeMensen. Despite coining it as a Netflix original, it was in fact a deal where Netflix co-financed, from the onset, and received worldwide exploitation rights in return. While various interviewees still consider co-productions a burdensome 'necessary evil', ${ }^{8}$ they do form a highly welcome source of input which helps overcome insufficient funding. When co-financiers are involved, creative autonomy still lies with the producer. In the case of actual co-production partners, interviewees indicated that they try to negotiate to keep as much autonomy as possible in Flanders.

For producers, involving a third-party co-producer helps increase the budget of their series. Averages show budgets have grown from 3.4 million Euro in 2015 to 5.2 million Euro in $2017 .{ }^{49}$ Involving a third-party co-producer also reduces the percentage of investment made by the broadcaster, putting producers in a more favourable position to negotiate rights and revenue splits. On their side, broadcasters would favour selling canned export rather than cofinance TV drama for the same reasons, as recoupment can immediately be split between broadcaster and producer, without having to cover distributors' minimum guarantees. In interviews, producers who have invested in TV drama currently see the involvement of non-Flemish co-production or co-financing partners as a core strategy to keep domestic Flemish drama competitive on international markets.

\section{Conclusions}

This article discussed the factors involved in the uptake of Flemish TV fiction exports. Rather than pinpointing one specific reason, a combination of factors has been identified as having contributed to this rise and helped label Flanders as a market of particular interest for international buyers. The international attention for Flemish content was initiated by the broadcast of a Flemish crime drama series by BBC Four. The availability of distribution outlets grew internationally both in over-the-top offerings and domestic pay-TV catalogues, which, despite the dominance of Anglo-Saxon content, also increased the offerings of fiction from small markets. Subsequently, more internationally appealing content was produced, with broadcasters and producers aiming to secure higher budgets. A more central focus was given to screenwriting and to more universal themes and high-concept premises. This led to the involvement of foreign funding either in the form of co-production partnerships or pre-financing deals with distributors. A clear outward-looking strategy of producers and broadcasters was formulated, in order to explore export potential, with an eye on return on investment in the project choices made. Investments were made in the promotion of TV fiction at international buyers' markets, following years of investing solely in film promotion. And finally, higher production grants were awarded for high potential TV dramas by the Flanders Audiovisual Fund.

Interestingly, the explanatory factors have a lot in common with the international uptake of Danish TV drama, which was also initiated by the success of Forbrydelsen (2007-2012) on BBC; involved securing higher budgets, amongst others based on partnerships with other Nordic countries (through Nordvision), and the involvement of ZDF as a production partner; involved DR Sales in securing part of the budget in order to raise export potential; and focused on high-quality screenwriting. However, there are also a number of differences as demonstrated in the works of, among others, Sparre and From, Hansen and Waade, Jacobsen and Redvall. ${ }^{50}$ Danish TV drama strategy set off from a common vision that was initiated by DR, with a clear focus to secure funding internationally by limiting resources on a specific volume of titles, thus reaching higher budgets and clear international appeal. They also placed the screenwriter at the head of production, installing writers' rooms, and included double narrative screenwriting involving combinations of authentic domestic and universally appealing themes, which allowed for keeping a tight grip on creative and production considerations. 
In Flanders, despite the public broadcaster being more actively involved in assisting and overseeing screenwriters throughout the development process, there was no common public service broadcasting strategy; this was set according to the production company, as they usually took the creative lead. A second fundamental difference is the fact that the adjustments made in media fund grants, budgets and VRT's outward focus can be seen more as a result, or at least a form of anticipation of continued success, rather than a cause. A third important difference is in the development of the Flemish TV drama 'brand'. Despite reviewers ${ }^{51}$ identifying a specific surrealism in the tone and pacing of Flemish drama, there was no common brand or aesthetic form to support its popularity. Other research, including the project 'What Makes Danish TV Drama Travel?'52 revealed that these typical creative features - lighting, pace, dark, female protagonists - were considered core 'ingredients' in Nordic Noir, which created expectations and reduced risk for buyers due to the consistency in style.

As a final point, despite the previous Flemish government's focus on export and internationalisation as part of making audio-visual content more sustainable, available figures and input from our interviewees also clearly showed the additional income was by no means sufficient to make TV drama in Flanders sustainable without government support. Over the past two decades, more government support did result in higher volumes and profits for producers and broadcasters, but it did not succeed in making the genre itself more sustainable. In recent years, motivations to invest more in TV drama have gradually shifted towards more cultural objectives, with screen agencies, governments and stakeholders increasingly emphasising the cultural value of displaying local content amidst the global streaming wars.

Exports allowed for larger budgets through foreign investments and led to higher productivity; however, the uptake in volume did not significantly lead to more sustainability given the continued dependence on even more tax and public funding support mechanisms. To this end, canned export sales provided important additional revenue for larger production companies like Caviar, DeMensen, and Woestijnvis, allowing more financial leeway to develop new content. Exports have also brought broadcasters an increase in revenue, pushing services such as the VRT to actively look for more opportunities in this area. In terms of market sustainability, exports have actually increased competition; higher production volumes require higher budgets, and they also add more pressure on creative talent and production crews, all this while reinforcing the dependence on public money. This is somewhat different from findings in earlier research on Danish drama, where co-productions and co-financing through funds like Nordvision did provide stable resources and income. However, the clear strategy of DR, which still produces most of its content inhouse, and the fact that only a limited number of players produce fiction in the market, did not lead to an explosion of new series. Nevertheless, the case of Flanders resembles multiple small markets which have seen an uptake in TV drama volumes, yet almost always due to support through additional funding schemes.

With an eye on the future, there are some considerations that policymakers and the industry could take into account. A first one relates to the role of private broadcasters in TV drama production. The fact that VRT is embracing more daring, high-end TV drama concepts, and has managed to secure stable funds for their projects, makes producers increasingly consider VRT as the prime outlet for their drama productions. This puts pressure on the position of private broadcasters in contributing to a flourishing and dynamic TV drama environment. Secondly, a common focus on internationalisation for broadcasters and producers has not reduced existing tensions between the two. The current focus on internationalisation and high concept can only work in accordance with maintaining content authenticity, in order to sustain domestic success and avoid compromising on quality. In interviews, broadcasters have claimed that they strive on matching high-end narratives, themes, screenwriting and production design with expectations from the broad Flemish audience. Thus far however, more daring concepts have not resulted in lower domestic success, on the contrary.

A final observation is that, whereas all branches of TV drama production over the past years have professionalised, screenwriting still proves challenging. ${ }^{53}$ Due to the high-speed production of Flemish drama, and the necessity to keep filming crews on set, production companies try to remain pragmatic. This often results in screenplays going into development or production too soon, but, as research has also shown, time to re-write and script edit is pivotal in 
developing successful TV drama. ${ }^{54}$ Further investment in screenwriting at the level of higher education and overcoming existing fragmentation among film schools in Flanders, as well as investing in script doctor/script editing training could add to increasing screenwriting expertise and investment in talent.

\section{Notes}

1. Gillian Doyle, "Resistance of Channels: Television Distribution in the Multiplatform Era," Telematics and Informatics 33 , no. 2 (2016); Amanda Lotz, We Now Disrupt This Broadcast: How Cable Transformed Television and the Internet Revolutionized It All (Cambridge, MA: MIT Press, 2018); Jeanette Steemers, "Blurred Lines: Public Service Media and the State," in Global Media and National Policies, eds. Terry Flew, Petros losifidis, and Jeanette Steemers (Basingstoke: Palgrave Macmillan UK, 2016).

2. Manuel Puppis, "Media Regulation in Small States," International Communication Gazette 71, no. 1-2 (2009).

3. Gregory F. Lowe, Christian E. Berg, and Christian S. Nissen, "Size Matters for TV Broadcasting Policy," in Small among Giants: Television Broadcasting in Smaller Countries, eds. Gregory F. Lowe and Christian S. Nissen (Göteborg: Nordicom, 2011); Caroline Pauwels, Cultuur En Economie: De Spanningsvelden van Het Communautair Audiovisueel Beleid. Een Onderzoek Naar de Grenzen En Mogelijkheden van Een Kwalitatief Cultuur- En Communicatiebeleid in Een Economisch Geïntegreerd Europa [Culture and Economy: The Fields of Tension in the Community's Audiovisual Policy. An analysis of the Limits and Possibilities of a Qualitative Culture and Communications Policy in an Economically Integrated Europe. A Critical Analysis and Prospective Evaluation Based on the European Audiovisual Policy] (Brussel: Vrije Universiteit Brussel, 1995); Dirk Wauters and Tim Raats, "Public Service Media and Ecosystem Sustainability. Towards Effective Partnerships in Small Media Markets," in Public Service Media in the Networked Society: RIPE@2017, eds. Gregory F. Lowe, Hilde van den Bulck, and Karen Donders (Göteborg: Nordicom, 2018).

4. Eva Novrup Redvall, Writing and Producing Television Drama in Denmark: From The Kingdom to The Killing (Basingstoke: Palgrave MacMillan, 2013).

5. Pia M. Jensen, Jakob I. Nielsen, and Anne M. Waade, "When Public Service Drama Travels: The Internationalization of Danish Television Drama and the Associated Production Funding Models," Journal of Popular Television 4, no. 1 (2016).

6. Jakob Stougaard-Nielsen, "Nordic Noir in the UK: The Allure of Accessible Difference," Journal of Aesthetics \& Culture 8, no. 1 (2016).

7. Vincent Mosco, The Political Economy of Communication (London: Sage, 2009).

8. Mark Lawson, "Is Belgian Drama the New Scandi-Noir?," The Guardian, February 22, 2018, https://www.theguardian.com/ tv-and-radio/2018/feb/22/is-belgian-drama-the-new-scandi-noir

9. Ruth McElroy, Jakob I. Nielsen, and Caitriona Noonan, "Small Is Beautiful? The Salience of Scale and Power to Three European Cultures of TV Production," Critical Studies in Television: The International Journal of Television Studies 13, no. 2 (2018): 169-87.

10. Doyle, "Resistance of Channels"; Wauters and Raats, "Public Service Media and Ecosystem Sustainability".

11. Christian E. Berg, "Sizing up Size on TV Markets. Why David Would Lose to Goliath," in Small among Giants: Television Broadcasting in Smaller Countries, eds. Gregory F. Lowe and Christian S. Nissen (Göteborg: Nordicom, 2011).

12. Puppis, "Media Regulation in Small States".

13. McElroy et al., "Small Is Beautiful?"; Tim Raats, Jeanette Steemers, and Karen Donders, "Is Content Still King? Trends and Challenges in the Production and Distribution of Television Content in Europe," in Comparative Media Policy, Regulation and Governance in Europe, eds. Leen D'Haenens, Helena Sousa, and Josef Trappel (Bristol: Intellect, 2018).

14. Robert Picard, "Broadcast Economics, Challenges of Scale, and Country Size," in Small among Giants: Television Broadcasting in Smaller Countries, eds. Gregory F. Lowe and Christian S. Nissen (Göteborg: Nordicom, 2011).

15. Econopolis, Doorlichting Vlaams Audiovisueel Beleid [Evaluation of the Flemish Audiovisual Policy], 2017; Econopolis, Productie, Aggregatie En Distributie van Audiovisuele Content in Vlaanderen [Production, Aggregation and Distribution of Audiovisual Content in Flanders], 2018.

16. European Audiovisual Observatory, Film Production in Europe - Production Volume, Co-Production and Worldwide Circulation (Strasbourg: EAO, 2017).

17. Doyle, "Resistance of Channels"; Catherine Johnson, Online Television (London: Routledge, 2019).

18. Catalina lordache and Eline Livémont, "Imbalances in On-Demand Documentary Offerings. The Case of a Small Media Market: Belgium", International Journal of Communication 12, (2018).

19. European Audiovisual Observatory, Audiovisual Media in Europe: Localised, Targeting and Language Offers (Strasbourg: EAO, 2018). 
20. European Audiovisual Observatory, The production and circulation of TV fiction in the EU28 Television and VOD (Strasbourg: EAO, 2018).

21. European Audiovisual Observatory, Film Production in Europe.

22. Kim Toft Hansen, Steven Peacock, and Sue Turnbull, eds., European Television Crime Drama and Beyond (Cham: Palgrave Macmillan, 2018).

23. Tim Raats, Ilse Schooneknaep, and Caroline Pauwels, "Supporting Film Distribution in Europe: Why Is Overcoming National Barriers so Difficult?," in Handbook of State Aid for Film: Finance, Industries and Regulation, eds. Paul Murschetz, Roland Teichmann, and Matthias Karmasin (Cham: Springer, 2018).

24. Joseph Straubhaar, World Television: From Global to Local (London: Sage, 2007).

25. Jensen et al., "When Public Service Drama Travels".

26. Eduard Cuelenaere, Stijn Joye, and Gertjan Willems, "Local Flavors and Regional Markers: The Low Countries and their Commercially Driven and Proximity-Focused Film Remake Practice," Communications 44, no. 3 (2019).

27. Jonathan Bignell and Andreas Fickers, eds, A European Television History (Oxford: Wiley-Blackwell, 2008); European Audiovisual Observatory, Audiovisual Media in Europe.

28. Tim Raats, Tom Evens, and Sanne Ruelens, "Challenges for Sustaining Local Audiovisual Ecosystems. Analysis of Financing and Production of Domestic TV Fiction in Small Media Markets," Journal of Popular Television 4, no. 1 (2016).

29. Since 2019, following the European Audiovisual Media Services Directive revision, the government also obliges on-demand players not based in Flanders but targeting the Flemish market (like Netflix) to contribute a percentage of their turnover in Flanders to audio-visual production; for more information see Karen Donders, Tim Raats, Marlen Komorowski, Ivana Kostovska, Stephanie Tintel, and Catalina lordache, Obligations on On-Demand Audiovisual Media Services Providers to Financially Contribute to the Production of European Works. An Analysis of European Member States' Practices (Brussels: imec-SMIT-Vrije Universiteit Brussel, 2018).

30. Econopolis, Productie, Aggregatie En Distributie van Audiovisuele Content in Vlaanderen, 9.

31. imec, Imec.Digimeter 2018. Measuring Digital Media Trends in Flanders, 2019, https://www.imec-int.com/nl/digimeter2018/ imec-digimeter-2018-download

32. Alexander Dhoest, "Negotiating Images of the Nation: The Production of Flemish TV Drama, 1953-89," Media, Culture \& Society 26, no. 3 (2004)

33. Alexander Dhoest, "The National Everyday in Contemporary European Television Fiction: The Flemish Case," Critical Studies in Television 2, no. 2 (2007).

34. Het Belang van Limburg, "Vermist Verkocht Aan Duitsland" [Vermist Sold to Germany], March 20, 2010, https://m.hbvl.be/cnt/ aid912376/vermist-verkocht-aan-duitsland; MVO, "'De Dag' Werd al in 32 Landen Verkocht' ['The Day' Already Sold to 32 Countries], February 1, 2019, https://www.hln.be/showbizz/tv/-de-dag-werd-al-in-32-landen-verkocht a279e7bc/

35. Econopolis, Productie, Aggregatie En Distributie van Audiovisuele Content in Vlaanderen.

36. Lawson, "Is Belgian Drama the New Scandi-Noir?".

37. Raats et al., "Challenges for Sustaining Local Audiovisual Ecosystems".

38. Jensen et al., "When Public Service Drama Travels".

39. Ib Bondebjerg, Eva Novrup Redvall, Rasmus Helles, Signe Sophus Lai, Henrik Søndergaard, and Cecilie Astrupgaard, Transnational European Television Drama: Production, Genres and Audiences (Cham: Springer, 2017); Hansen et al., European Television Crime Drama and Beyond.

40. Redvall, Writing and Producing Television Drama in Denmark.

41. Ruth McElroy, 'What Can Wales Learn from Nordic Noir?', CST Online, November 15, 2013, https://cstonline.net/what-canwales-learn-from-nordic-noir-by-ruth-mcelroyl

42. Bondebjerg et al., Transnational European Television Drama.

43. VRT Fiction Advisor, Interview with authors, August $4^{\text {th }}, 2018$; Medialaan Head of Fiction, Interview with authors, June $16,2016$.

44. VRT Fiction Advisor, Ibid.; Showrunner, Interview with authors, October 10, 2016.

45. Tom Evens and Karen Donders, Platform Power and Policy in Transforming Television Markets (Cham: Springer, 2018).

46. Minister of Media, Beleidsbrief Media 2015, Flemish Government, 2015; Minister of Media, Beleidsbrief Media $2016,2016$.

47. Tim Raats, Tom Evens, Annelies Appeltans, and Stephanie Tintel, Stakeholderbevraging VRT Beheersovereenkomst [Stakeholder Inquiry VRT Management Contract], imec-SMIT-Vrije Universiteit Brussel, 2019.

48. Producer, Interview with authors, March 4, 2019.

49. Econopolis, Productie, Aggregatie En Distributie van Audiovisuele Content in Vlaanderen.

50. Kirsten Sparre and Unni From, "Journalists as Tastemakers: An Analysis of the Coverage of the TV Series Borgen in a British, Swedish and Danish Newsbrand," in Cultural Journalism in the Nordic Countries, eds. Kristensen K. Nørgaard and Kristina Riegert (Göteborg: Nordicom, 2017), 159-78; Kim Toft Hansen and Anne M. Waade, Locating Nordic Noir: From Beck to The Bridge (Cham: Palgrave Macmillan, 2017); Ushma C. Jacobsen, "Does Subtitled Television Drama Brand the Nation? Danish Television Drama and Its Language(s) in Japan," European Journal of Cultural Studies 21, no. 5 (2018); Redvall, Writing and Producing Television Drama in Denmark. 
51. Lawson, "Is Belgian Drama the New Scandi-Noir?".

52. http://danishtvdrama.au.dk/

53. Producer, Interview with authors; VAF, Interview with authors, June $11^{\text {th }}, 2017$.

54. Redvall, Writing and Producing Television Drama in Denmark.

\section{Biographies}

Tim Raats is a professor at the Department of Communication Sciences at the Vrije Universiteit Brussels, and head of the Media Economics and Policy research unit at imec-SMIT, Vrije Universiteit Brussel. His research focuses on public service media policy, with a particular focus on partnership strategies, and sustainability of TV production in small media markets. Tim coordinated several research projects for the Flemish Minister of Media, the Department of Culture, Youth, Sports and Media in Flanders, the Flemish Sector Council for Media and the VRT. Since 2018, he is an appointed board member of the Flanders Audiovisual Fund (VAF).

Catalina lordache is a doctoral researcher in media and communication studies at the research group imec-SMIT, Vrije Universiteit Brussel, and a teaching assistant for the Bachelor's in Social Sciences programme. She is currently writing her PhD dissertation on the transnational flow of audiovisual content in the online environment, with a focus on media policy, and the production and distribution of audiovisual content. Her previous research topics include media literacy, digital literacy, and e-inclusion. 